https://ojs.tdmu.edu.ua/index.php/kl-stomat

УДК 378.147+614.253.4+616.314

DOI 10.11603/2311-9624.2020.1.12043

(C). М. Ільницька, А. Б. Костишин

Івано-Франківський національний медичний університет

e-mail: oleksandraif@gmail.com

\title{
Дистанційна форма навчання на післядипломній освіті підготовки лікарів-інтернів-стоматологів: міф чи реальність
}

\section{ІНФОРМАЦІЯ}

Надійшла до редакції/Received: 02.02.2021 p.

Ключові слова: дистанційне навчання; дистанційне навчання лікарів-інтернів; лікарстоматолог; післядипломна освіта; маніпуляційна стоматологічна допомога.

\section{АНОТАЦІЯ}

Резюме. На сьогодні прогресивним у розвитку нашого інформаційного суспільства сфери технологій виступає дистанційна освіта як нова освітня парадигма розвитку освітньо-інформаційного простору.

Мета дослідження - розглянути та визначити значення дистанційної форми навчання на процес професійної підготовки лікарів-інтернів стоматологів на етапі післядипломної освіти. Також довести недоцільність запровадження дистанційного навчання у післядипломній освіті лікарів-стоматологів.

3 огляду на це, у статті актуалізовано проблему дистанційної форми навчання лікарів-інтернів на етапі післядипломної підготовки фахівців у сфері стоматології. Розкривається поняття дистанційного навчання та його плюси і мінуси у підготовці лікарів-інтернів. Запропоновано власні визначення понять «дистанційне навчання» та «дистанційне навчання лікарів-інтернів». Розглянуто деякі моменти нормативно-правового регулювання безперервного професійного розвитку фахівців з охорони здоров'я та особливості правового регулювання надання стоматологічних послуг. Визначено значення дистанційного навчання у професійному становленні лікаря-стоматолога на етапі його післядипломної підготовки, адже така форма навчання є недоцільною для одержання освіти і підвищення кваліфікації на даному етапі професійного розвитку. Також з'ясовано ефективність дистанційного навчання у професійному розвитку лікарів-стоматологів на етапі післядипломної освіти шляхом відповідей на актуальні суспільні запитання в медичній освіті. Оскільки використання дистанційної форми навчання на етапі післядипломної підготовки лікаря-інтерна не дасть позитивного впливу на рівень професійної підготовки і готовності майбутнього стоматолога до виконання своїх професійних обов'язків, де професійні вміння і навики набуваються в процесі безпосереднього контакту з пацієнтом.
Вступ. Інтеграція України в світовий освітній простір вимагає постійного удосконалення національної системи освіти, пошуку ефективних шляхів підвищення якості освітніх послуг, апробації та впровадження інноваційних педагогічних систем, реального забез- печення рівного доступу всіх їі громадян до якісної освіти, можливостей і свободи вибору в освіті, модернізації змісту освіти й організації їі адекватно світовим тенденціям і вимогам ринку праці, забезпечення безперервності освіти та навчання протягом усього життя, 
розвитку державно-громадської моделі управління [19]. Тому наше інформаційне суспільство розвивається надзвичайно швидко завдяки розвитку науки та практики, що, у свою чергу, вимагає висококваліфікованих фахівців із професійно сформованими знаннями, уміннями та навиками. Даний фахівець має бути інформаційно обізнаним, постійно засвоювати новітні технології, розвивати набуті знання та вміння, безперервно підвищувати свій професійний рівень та використовувати інноваційні технології навчання (в нашому випадку дистанційне навчання), що ефективно підвищить навчальний процес та міститиме більшу результативність праці завдяки удосконаленню професійної компетентності.

Застосування інноваційних методів навчання сприятиме підвищенню кваліфікації лікарів-інтернів для удосконалення своїх професійних знань та умінь в умовах сучасного інформаційного суспільства. Що стосується дистанційної форми навчання лікарів-інтернів, то вона викликає низку суперечностей, які розглянуто нижче. Різноманітні аспекти дистанційного навчання можна побачити у працях С. О. Баган, К. О. Бур'ян, Л. В. Галій, І. В. Козлова, О. Л. Малиновської, С. Р. Масон, П. В. Нартов, Т. Б. Тарасової, О. А. Чаплик, Л. І. Шульга, В. А. Якущенко та ін. А дистанційне навчання у післядипломній освіті лікарів-інтернів розглядали такі науковці, як Т. Ю. Кравченко, М. В. Мельничук, Л. Ю. Мінько, Я. В. Семкович, В. Д. Скрипко тощо.

Метою дослідження було розглянути та визначити значення дистанційної форми навчання на процес професійної підготовки лікарів-інтернів стоматологів на етапі післядипломної освіти. Також довести недоцільність запровадження дистанційного навчання у післядипломній освіті лікарів-стоматологів.

Під дистанційною освітою розуміють комплекс освітніх послуг, який надається за допомогою інформаційно-навчального середовища, що базується на засобах обміну навчальною інформацією на відстані. Дистанційна освіта в медицині виконує дві основні функції: підвищення рівня освіченості та задоволення потреб в освітніх послугах [3].

Дистанційне навчання - цілеспрямований, організований процес активної взаємодії тих, хто навчає і тих, хто навчається за допомогою засобів навчання, які є іншими варіантними у просторі й часі та які реалізуються у специфічній дидактичній системі [2].
Сьогодні дистанційне навчання розглядається як форма організації і реалізації навчально-виховного процесу, за якою його учасники здійснюють навчальну взаємодію переважно екстериторіально (тобто на відстані, коли слухач і викладач фізично відокремлені відстанню, яка не дозволяє і не передбачає безпосередню навчальну взаємодію учасників віч-на-віч, інакше кажучи, коли учасники територіально знаходяться поза межами можливої безпосередньої навчальної взаємодії і коли у процесі навчання їх особиста присутність у певних навчальних приміщеннях навчального закладу не є обов'язковою, а систематичне відвідування занять не передбачається) [13].

Також необхідно розглянути дистанційне навчання у підготовці лікарів-інтернів, під яким розуміють як сучасну організацію навчального процесу, яка реалізується у специфічній педагогічній системі, що базується на принципі самостійного навчання лікаря та інтерактивної взаємодії викладача і лікаря-інтерна [11].

На основі викладеного запропоновано визначення дистанційного навчання як організованого та цілеспрямованого навчальновиховного процесу активної дистанційної взаємодії ï̈ учасників. Тоді як під дистанційним навчанням лікарів-інтернів - це форма організації навчально-виховного процесу дистанційної взаємодії педагога і лікаря-інтерна, що базується на відповідальне та самостійне навчання майбутніх лікарів.

Система дистанційного навчання у поточний час продовжує своє бурхливе поширення. Немає сумнівів, що дистанційне навчання увійде в XXI ст. як найефективніша система підготовки і безперервної підтримки високого рівня кваліфікації фахівців. Будь-який вищий навчальний заклад або викладач вже не зможе вважатися носієм високої педагогічної майстерності, якщо не володіє засобами, методами і технологіями дистанційного навчання [6]. Але необхідно врахувати той факт, що застосування дистанційної форми навчання в медичній освіті підготовки лікарів-стоматологів можливе лише протягом перших п'яти років і тільки на теоретичних заняттях. Щодо підготовки даної категорії медиків на післядипломній медичній освіті дистанційне навчання не може бути, оскільки жодний курс не може надати маніпуляційних навиків та вмінь, що полягає у наданні безпосередньо стоматологічної допомоги виконанням набу- 
тих стоматологічних навичок, вмінні роботи лікаря-стоматолога 3 ротовою порожниною, розширенні зубчика тощо. Тобто надання стоматологічної допомоги не може бути проведено онлайн, тільки безпосередній контакт лікар-пацієнт.

Згідно із Загальною Декларацією прав людини, обов'язком держави є піклування про здоров'я людини і забезпечення його охорони. Ядром охорони здоров'я виступають медичні відносини, які виникають між пацієнтом і лікарем (медичним працівником) з приводу надання медичної допомоги (Н. Б. Болотіна). Медичні відносини регулюються Конституцією України, Основами законодавства України про охорону здоров'я, Законами України та цілим рядом інших нормативно-правових актів [17].

Також враховуючи різноманітні реформи у галузі освіти та охорони здоров'я, система безперервного професійного розвитку фахівця у сфері охорони здоров'я (БПР) едосконалювалася шляхом прийняття Положення про систему безперервного професійного розвитку фахівців у сфері охорони здоров'я, затвердженому Постановою Кабінету Міністрів України № 302 від 28.03.2018 р. Це положення визначає основні організаційні засади безперервного процесу навчання та удосконалення професійних компетентностей фахівців після здобуття ними вищої освіти у сфері охорони здоров'я та післядипломної освіти. У ньому наголошується, що безперервний процес навчання лікарів дозволить підтримувати та поліпшувати стандарти їх професійної діяльності відповідно до потреб сфери охорони здоров'я та триватиме упродовж усього періоду професійної діяльності [1].

Підготовка лікарів-професіоналів-стоматологів нового покоління невід’ємна від перебудування системи медичної освіти, що базується на процесі «освіта впродовж життя», який $€$ основою для програми ЮНЕСКО «Освіта для XXI століття». На сьогодні підготовка фахівця лікаря-стоматолога потребує необхідність певних змін на післядипломному етапі навчання 3 урахуванням міжнародного досвіду підвищення якості медичної освіти, що вимагає розробки нових науково-педагогічних підходів, інновацій. Формування компетентного лікаря-стоматолога починається на першому курсі університету та продовжується все «стоматологічне» життя людини. Інтернатура - одна з головних ступенів цього процесу i, безумовно, залежить від якості освіти, рівня професорсько-викладацького складу. Особливо це питання стає гостро у наш час, коли випускник кафедр післядипломної підготовки має шанс працевлаштування як у себе на Батьківщині, так і в країнах Європи. Тому важливою проблемою післядипломної освіти стає її компетентнісне наповнення, розвиток професійної компетентності лікаря-стоматолога-інтерна [21].

Основним завданням у сучасній післядипломній освіті є перехід від концепції набуття знань, умінь і оволодіння практичними навичками до концепції освіти, що всебічно розвиває лікаря як особистість. У теперішніх реаліях потрібно використовувати найбільш ефективні методи навчання, відповідно до дисципліни, які дадуть позитивний наслідок, та базуватимуться на трьох складових: теоретичний курс, стимуляційний тренінг та клінічне навчання [9]. Тобто післядипломна освіта має здійснюватися шляхом оволодіння практичних вмінь та навичок, коли знання здобуті раніше починають застосуватися у процесі практичної діяльності шляхом набуття практичного досвіду в роботі безпосередньо $з$ клієнтами.

При розгляді структури післядипломної освіти фахівців охорони здоров'я відзначаємо, що під час навчання фахівець отримує бали, які мають бути підтверджені відповідними документами (дипломи, посвідчення, сертифікати тощо) та фіксуються в особистому освітньому портфоліо, яке щорічно контролюється органом, при котрому створено атестаційну комісію щодо відповідності вимогам, встановленим МОЗ України. Однією з переваг даного Положення є те, що офіційно визнається дистанційне навчання (ДН), у тому числі отримання дистанційної освіти шляхом електронного навчання за допомогою Інтернет-ресурсів [16, 18], що має свої переваги та недоліки.

У даний час дистанційне навчання в усьому світі, в тому числі й в Україні, розвивається виключно активно. Дистанційне навчання відрізняється низкою суттевих психолого-педагогічних переваг:

- можливість навчатися у будь-який час;

- можливість навчатися у своєму темпі;

- можливість навчатися у будь-якому місці;

- навчання без відриву від основної діяльності;

- високі результати навчання;

- мобільність; 
- доступність навчальних матеріалів;

- навчання в спокійній обстановці;

- індивідуальний підхід;

- зручність для викладача;

- професійне зростання викладача.

Дистанційна форма навчання є однією із ведучих форм навчання в світі, яка охоплює засоби спілкування аудиторії через чати, блоги, форуми, відеотрансляції. Дана форма навчання має ряд переваг. Зокрема, здобувач вищої освіти може навчатися в зручний для нього час, у звичному оточенні та у відносно автономному темпі [15].

Однак поряд із наявністю таких безсумнівних переваг, дистанційне навчання обмежує можливості безпосереднього спілкування учнів, студентів з педагогами, що значно знижує розвивальний і виховний потенціал навчання [23]. Тому необхідним є збереження традиційної форми навчання або змішаної, оскільки це дасть можливість набути майбутнім лікарям-інтернам низку різних компетентностей (наприклад, комунікативних, спеціальних). Оскільки деякі теоретичі курси лікарям-інтернам стоматологічного факультету можна проводити дистанційно (наприклад,.........), а деякі змішаною формою навчання (наприклад,........). Тобто дистанційне навчання можна застосовувати для тих навчальних дисциплін, де майбутні лікарі-стоматологи набудуть загальної компетентності. Але що стосується практичних занять, то тільки традиційною формою навчання, де присутній безпосередній контакт лікаря-інтерна-стоматолога з пацієнтом.

Необхідність зміни вітчизняної системи післядипломної медичної освіти зумовлена численними факторами: стрімким зростанням обсягів медичних відомостей; швидкою зміною самого розуміння подій, фактів, явищ; недостатнім часом на передавання необхідних знань; нескінченним розмаїттям фізіологічних і патологічних станів організму людини тощо [5]. Дистанційна форма навчання удосконалює післядипломну підготовку лікарів-інтернів. Головною метою викладання в післядипломній освіті є досягнення якісної практичної підготовки на підставі знань, умінь та навичок за традиційними й новітніми навчальними технологіями. Інновації у післядипломній освіті передбачають впровадження у технології навчання лікарів-інтернів на базах стажування дистанційного навчання. Дистанційне навчання передбачає декілька різних технологій, які можуть використовуватися в навчальному процесі: кейсову технологію, інтернет-технологію та телекомунікаційну технологію [10].

Тому сучасне суспільство ставить перед нами усіма ряд невирішених питань щодо післядипломної підготовки лікарів-стоматологів дистанційної форми навчання, зокрема: Як сучасна українська медична післядипломна освіта має перейти на онлайн-навчання?, Як можна навчити лікаря-інтерна надавати дистанційно маніпуляційну стоматологічну допомогу? і Чи можливо надання дистанційної стоматологічної допомоги і в яких випадках?, що нижче розглянуті.

Як сучасна українська медична післядипломна освіта має перейти на онлайн-навчанНя?

Кожний лікар-інтерн, який знаходиться на відстані від головної бази університету, завдяки комп'ютерним телекомунікаційним технологіям має можливість ознайомитися 3 методичними розробками лекцій, семінарських та практичних занять, одержати консультативну допомогу у викладачів кафедри, брати участь у телеконференціях. Лікарі виконують індивідуальні завдання, що заплановані у дистанційному курсі. Практичні заняття виконують дистанційно. Результати надсилаютьвикладачеві електронною поштою [12].

Результативність дистанційного навчання на післядипломному етапі освіти лікарів визначається: ефективністю взаємодії викладача і лікаря; активним зворотним зв’язком; якістю попереднього проектування процесу дистанційної освіти і засобами управління ним; розробкою дидактичних матеріалів [24].

Так, головною проблемою сьогодення $є$ недостатній технічний рівень підготовки професійних кадрів за фахом для роботи за принципами дистанційної освіти, а також обмеження навчально-методичного забезпечення, яке концептуально відповідало б вимогам дистанційного навчання, неврегульованість проблем як захисту інтелектуальної власності авторів проектів, так і права та фінансової спроможності викладачів щодо використання матеріалів мережі «Інтернет». Але поряд 3 цим необхідно відзначити, що післядипломна підготовка вимагає від викладача постійного осучаснення навчального матеріалу, кожний викладач постійно оновлює інформацію для лекційних та семінарських занять. Надання вищеозначеного для відкритого користу- 
вання призводить до втрати ексклюзивності матеріалу, що свідчить про актуальність вирішення питань патентного захисту ДК. Післядипломна підготовка за своїм призначенням має давати новітній матеріал - показувати зміни нормативно-правової бази, висвітлювати останні досягнення вчених, відстежувати зміни в практиці охорони здоров'я [7].

Таким чином, сучасне інформаційне суспільство вимагає від населення знань та вмінь роботи з комп’ютером (комп’ютеризація), в тому числі й у галузі науки та освіти, де у закладах вищої освіти створено або створюються відділи дистанційної освіти. Головним щодо цього є запровадження сучасних методик дистанційної форми навчання лікарів у післядипломній освіті, де медичне навчання стане не тільки очним, але і заочним.

Дистанційне навчання лікарів-інтернів сприятиме їх мобільності та участі в онлайнконференціях відомих українських та зарубіжних спеціалістів з галузі медичної освіти. Також свідчитиме про економність праці та можливість працювати 3 кожним лікарем індивідуально. Але при цьому обов'язковим має бути очне ознайомлення з новими методами роботи з пацієнтами, наданні консультації викладачів у процесі практичних занять, урахування та ознайомлення з досвідом спеціалізованих клінік тощо.

Як можна навчити лікаря-інтерна надавати дистанційно маніпуляційну стоматологічну допомогу?

Дистанційне навчання активно впроваджується в навчальний процес післядипломної освіти УМСА, а саме на кафедрах післядипломної освіти лікарів-стоматологів і в тому числі. Отже, сучасні інформаційні технології $\epsilon$ вельми перспективними в організації неперервної професійної освіти. Вони дозволяють кожному з студентів опрацювати свій індивідуальний темп навчання, підібрати найефективніші методи навчання, спілкуватися безпосередньо 3 викладачами в будь-який час у міру необхідності та навіть складати заліки та іспити, не виходячи з дому. Тому головними найближчими завданнями педагогічної науки є створення, апробування та впровадження в масову практику новітніх інформаційних технологій 3 використанням комп’ютерних телекомунікаційних мереж [8]

Проте не усі слухачі циклів післядипломного удосконалення позитивно сприймають дистанційну форму навчання, найчастіше по- яснюючи свої сумніви наступними моментами [22]:

- дистанційне навчання сприймається як складніше з ряду причин - від недостатнього володіння комп’ютерною технікою до небажання працювати самостійно. Очне навчання, котре грунтується на лекціях і, зазвичай, завершується заліком або іспитом із мінімальною ймовірністю невдачі, не висуває великих вимог до тих, хто навчається. На противагу цьому, дистанційне навчання вимагає самоосвіти і звичної присутності на заняттях недостатньо;

- слухачі мають недовіру до електронних засобів комунікації. Останнє пов’язане з припущенням про те, що в інтернеті можуть публікуватись недостовірні (науково необгрунтовані дані), а навчальні установи знаходяться під суворим контролем і пропонують найбільш якісну освіту;

- у слухачів існує страх перед технічними засобами навчання; далеко не всі слухачі уміють користуватися комп’ютерами та всесвітньою мережею.

Як засвідчує практичний досвід у галузі стоматології ортопедичної, пов'язаної з технічним компонентом виконання медичної послуги - виготовлення і встановлення зубного протеза, пацієнти найчастіше вважають себе спроможними давати правильну оцінку якості виконаної послуги.

При зверненні до стоматологічної поліклініки для лікування метою пацієнта стає не якась там медична дія, втручання, маніпуляція, виготовлення зубного чи іншого протеза, а наступне:

- усунення причини та симптомів захворювання, травми, патологічного стану, змін і деформацій;

- стабілізація змін процесів в організмі;

- відновлення функцій органів, гомеостазу, програми природних змін організму, а інколи й сповільнення інволюційних процесів;

- покращення соматичного та психологічного стану;

- продовження терміну функціонування окремих органів, систем організму і, відповідно, усього організму в цілому;

- попередження розвитку і виникнення патологічних процесів, деформацій, змін;

- можливість соціальної адаптації в навколишньому середовищі [4].

Безумовно, на основі попередньо сказаного навчити лікаря-інтерна надавати стомато- 
логічну допомогу дистанційним способом $є$ неможливим. Оскільки жодний курс і жодна онлайн-консультація не може надати маніпуляційних навиків, тільки має бути безпосередній контакт лікаря-інтерна 3 ротовою порожниною пацієнта.

Чи можливо надання дистанційної стоматологічної допомоги і в яких випадках?

Разом 3 тим, існують певні складнощі, які необхідно враховувати при введенні в процес навчання дистанційної форми. По-перше, дистанційне навчання вимагає значних кваліфікованих трудовитрат для розробки і виробництва програм, які гарантують високу якість навчання. I, по-друге, забезпечення контролю клінічного досвіду. При дистанційному навчанні важко забезпечити розвиток клінічних умінь без інтегрованого навчання «обличчям до обличчя», «з рук в руки». Тому це вимагає ретельного планування для забезпечення належного змішування можливостей навчання, відповідних тимчасовим можливостям учнів [25].

Також лікар повинен особливо детально інформувати свого пацієнта за трьома основними питаннями [14]:

Роз'яснення $з$ приводу діагнозу. Дуже важливо, якщо від усвідомлення дійсного стану справ залежить рішення пацієнта погодитися на метод лікування, який пропонується;

Інформування щодо плану лікування. До даного питання відноситься і погодження приблизної ціни лікування. Лікар повинен також інформувати хворого про існуючі альтернативні методи лікування;

Інформування про типові ризики, що пов'язані з лікуванням, про можливий їх вплив на якість життя пацієнта в майбутньому.

Одним 3 найбільш розвинених напрямів у дистанційному навчанні $є$ телемедицина (відеоконференції, відеоконсультації і т. д.). Телемедицина може ефективно забезпечувати консультації та медичну допомогу в сільських районах пацієнтам, для яких своєчасність втручання є вирішальним фактором [20].

Отже, надання дистанційної стоматологічної допомоги неможливе, оскільки контакт між лікарем та пацієнтом має бути безпосереднім для правильного встановлення діагнозу та призначення лікування. Дистанційно можна зібрати аналоги, а точності при цьому не буде як при маніпуляційному огляді пацієнта. Тому дистанційне навчання лікаря-інтерна стоматологічного напрямку на післядипломній освіті неможливе, адже тоді належної маніпуляційної стоматологічної допомоги не буде надано, де надання такої допомоги вимагає безпосереднього контакту з ротовою порожниною пацієнта.

Таким чином, підготовка лікаря-стоматолога для надання стоматологічної допомоги є довгим та трудомістким процесом, що має здійснюватися в процесі практичної діяльності.

Висновки. На сучасному етапі розвитку суспільства дистанційна форма навчання на післядипломній освіті лікарів-інтернів стоматологічного факультету набуває все більшої актуальності, висуваючи при цьому нові вимоги підготовки медичного фахівця своєї справи. Правильна організація дистанційного навчання сприятиме якісному засвоєнню матеріалу на теоретичному рівні, але не на практичному, яке потребує засвоєнню маніпуляційних навичок лікаря-інтерна з пацієнтом безпосередньо шляхом надання йому стоматологічної допомоги. Загальні компетенції лікарів-інтернів стоматологічного напрямку формуються при набутті базисних знань, отриманих із дисциплін загального характеру, що має результат при вивченні дисциплін загального характеру при дистанційному навчанні.

Безумовно, що завершальним етап формування лікаря-стоматолога як професіонала своєї справи, є саме післядипломна освіта від організації та проведення якої залежатиме майстерність, професіоналізм та рівень комунікативності з людьми. Навчання на післядипломній освіті лікарів-стоматологів потребуе практичного навчання, де засвоюються практичні маніпуляційні вміння та навики роботи стоматолога з надання безпосередньо стоматологічної допомоги пацієнтові. Це, у свою чергу, вимагає не дистанційного контакту з викладачем, а традиційного контакту безпосереднього спілкування. Тому дистанційна форма навчання не може замінити традиційне навчання, а може тільки його доповнити як професійне. Але це стосується навчання протягом перших п'яти років, де можливе поєднання різних форм навчання. А щодо форми навчання на післядипломній освіті, то тільки доцільною виступає традиційно очне навчання. 


\title{
(С. М. Ильницкая, А. Б. Костышин
}

Ивано-Франковский национальный медицинский университет

\section{Дистанционная форма обучения на последипломном образовании подготовки врачей-интернов-стоматологов: миф или реальность}

\begin{abstract}
Резюме. На сегодняшнее время прогрессивным в развитии нашего информационного общества сферы технологий выступает дистанционное образование как новая образовательная парадигма развития образовательно-информационного пространства.

Цель исследования - рассмотреть и определить значение дистанционной формы обучения на процесс профессиональной подготовки врачей-интернов- стоматологов на этапе последипломного образования. Также доказать нецелесообразность введения дистанционного обучения в последипломном образовании врачей-стоматологов.

Учитывая это, в статье актуализировано проблему дистанционной формы обучения врачей-интернов на этапе последипломной подготовки специалистов в сфере стоматологии. Раскрывается понятие дистанционного обучения и его плюсы и минусы в подготовке врачей-интернов. Предложено собственные определения понятий «дистанционное обучение» и «дистанционное обучение врачейинтернов». Рассмотрены некоторые моменты нормативно-правового регулирования непрерывного профессионального развития специалистов по охране здоровья и особенности правового регулирования предоставления стоматологических услуг. Определены значения дистанционного обучения в профессиональном становлении врача-стоматолога на этапе его последипломной подготовки, ведь такая форма обучения является нецелесообразной для получения образования и повышения квалификации на данном этапе профессионального развития. Также выяснено эффективность дистанционного обучения в профессиональном развитии стоматологов на этапе последипломного образования путем дачи ответов на актуальные общественные вопросы в медицинском образовании. Поскольку использование дистанционной формы обучения на этапе последипломной подготовки врача-интерна не даст положительного влияния на уровень профессиональной подготовки и готовности будущего стоматолога к выполнению своих профессиональных обязанностей, где профессиональные умения и навыки приобретаются в процессе непосредственного контакта с пациентом.
\end{abstract}

Ключевые слова: дистанционное обучение; дистанционное обучение врачей-интернов; врачстоматолог; последипломное образование; манипуляционная стоматологическая помощь.

\section{(C). M. Ilnytska, A. B. Kostyshyn}

Ivano-Frankivsk National Medical University

\section{Distance form of education on postgraduate education of training of internal dentists: myth or reality}

Summary. At present, distance education as a new educational paradigm of development of educational and information space is progressive in the development of our information society in the field of technologies. The aim of the study - to consider and determine the importance of distance learning for the process of professional training of dentists-interns at the stage of postgraduate education. Also to prove the inexpediency of the introduction of distance learning in postgraduate education of dentists.

In view of this, the article actualizes the problem of distance education of interns at the stage of postgraduate training of specialists in the field of dentistry. The concept of distance education and its pros and cons in the training of interns is revealed. Own definitions of "distance education" and "distance education of interns" are offered. Some aspects of normative-legal regulation of continuous professional development of health care specialists and peculiarities of legal regulation of dental services are considered. The importance of distance education in the professional development of a dentist at the stage of his postgraduate training is determined, because this form of education is impractical for education and training at this stage of professional development. The effectiveness of distance education in the professional development of dentists at the stage of postgraduate education by answering current social issues in medical education is also clarified. Because, the use of distance education at the stage of postgraduate training of an intern will not have a positive impact on the level of professional training and readiness of the future dentist to perform their professional duties, where professional skills and abilities are acquired in the process of direct contact with the patient. 
Key words: distance education; distance education of interns; dentist; postgraduate education; manipulative dental care.

\section{СПИСОК ЛІТЕРАТУРИ}

1. Про затвердження Положення про систему безперервного професійного розвитку фахівців у сфері охорони здоров'я : Постанова Кабінету Міністрів України від 28 березня 2018 р. № 302.

2. Андреев А. А. Дистанционное обучение: сущность, технология, организация / А. А. Андреев, В. И. Солдаткин. - М. : Изд-во МИЭСИ, 1999. - 196 с.

3. Афанасьева А. А. Экспертные методы принятия решений о выборе системы дистанционного обучения для последипломного медицинского образования / А. А. Афанасьева, А. С. Афанасьев // Труды XV Всероссийской научно-методической конференции «Телематика 2008». - СПб., 2008. - С. 256.

4. Безпрозванна В. М. Особливості правового регулювання надання стоматологічних послуг / В. М. Безпрозванна, I. М. Паращич // Медичне право України: правовий статус пацієнтів в Україні та його законодавче забезпечення (генезис, розвиток, проблеми і перспективи вдосконалення) : матеріали II Всеукр. наук.-практ. конф. 17-18 квіт. 2008 р., Львів. - Львів : Вид-во ЛОБФ «Медицина і право», 2008. - С. 30-33.

5. Вороненко Ю. В. Безперервний професійний розвиток лікарів і провізорів - нові принципи побудови системи / Ю. В. Вороненко, О. П. Мінцер // Медична освіта. - 2011. - № 2. - С. 41-44.

6. Організація дистанційного навчання. Створення електронних навчальних курсів та електронних тестів : навч. посіб. / В. В. Вишнівський, М. Р. Гніденко, Г. І. Гайдур, О. О. Ільїн. - К. : ДУТ, 2014. - 147 с.

7. Впровадження дистанційної форми навчання в систему післядипломної освіти : проблемні питання сьогодення / Л. В. Галій, Л. І. Шульга, В. А. Якущенко [та ін.] // Проблеми безперервної медичної освіти і науки. - 2019. - № 3. - С. 14-20.

8. Гуревич Р. С. Інформаційно-комунікаційні технології в навчальному процесі і наукових дослідженнях / Р. С. Гуревич, Р. С. Кадемія. - К. : Освіта України, 2007. -396 c.

9. Григорьев Н. Н. Актуальные вопросы обучения хирургии / Н. Н. Григорьев, Е. А. Бобровская, С. Н. Григорьев // Современные проблемы науки и образования. - 2016. - № 4. - URL: http://www.scienceeducation.ru/ru/article/view?id=24912 (дата обращения: 06.12.2020).

10. Дистанционные образовательные технологии: проектирование и реализация учебных курсов / М. Б. Лебедева, С. В. Агапонов, М. А. Горюнова [и др.] ; под ред. М. Б. Лебедевой. - СПб. : БХВ-Петербург, 2010. - 336 с.

11. Дудина М. Н. Новая образовательная парадигма: проблемы содержания образования / М. Н. Дудина // Образование и наука. - 2010. - № 2. - С. 3-16.

12. Єщенко А. В. Використання дистанційного навчання в системі післядипломної освіти: сучасне і майбутнє / А. В. Єщенко // Проблеми безперервної медичної освіти та науки. - 2013. - № 2 (10). - С. 5-10.
13. Каркавина Д. Ю. Настольная книга пациента, или как защитить свои права при обращении за медицинской помощью / Д. Ю. Каркавина. - Ростовна-Дону : Феникс, 2007. - 352 с.

14. Ковальчук Л. Я. Основні тенденції розвитку світової вищої школи. Впровадження сучасних технологій в навчальний процес Тернопільської державної медичної академії ім. І. Я. Горбачевського: досягнення і перспективи / Л. Я. Ковальчук // Медична освіта. - 2000. - № 2. - С. 5-11.

15. Кухаренко В. М. Дистанційне навчання: умови застосування: навч. посіб. / В. М. Кухаренко, О. В. Рибалко, Н. Г. Сиротинко. - 3-є вид. - Харків : НТУ «ХПІ», Торсінг, 2002. - 320 с.

16. Медичне право України: Збірник нормативноправових актів / упоряд. і наук. ред. Н. Б. Болотіна. - Видавничий Дім : «Ін Юре», 2001. - 412 с.

17. Меркулова О. Г. Современный этап развития общества: проблема терминологии / О. Г. Меркулова // Междисциплинарные исследования в науке и образовании. - 2012. - № 1. - С. 26-30.

18. Національна стратегія розвитку освіти в Україні на 2012-2021 роки [Електронний ресурс]. - 2012. Режим доступу: http://www.nmu.edu.ua/legis2.php.

19. Ольнев А. С. Использование новых технологий в дистанционном обучении / А. С. Ольнев // Актуальные проблемы современной науки. - 2015. № 1. - С. 96.

20. Соколова I. I. Питання формування професійної компетентності лікаря-стоматолога в інтернатурі / I. І. Соколова, О. Ю. Стоян, О. Г. Денисова // Сучасний стан та перспективи підготовки лікарів-інтернів у Харківському національному медичному університеті : матеріали 43-ї наук.-метод. конф., присвяченої 50-річчю започаткування інтернатури в Харківському національному медичному університеті. Харків : ХНМУ, 2017. - 100 с.

21. Симчук Х. С. Перспективи та проблеми безперервної освіти в сімейній медицині / Х. С. Симчук // Буковинський медичний вісник. - 2016. - № 4 (80). C. 246-249.

22. Тарасова Т. Б. Використання елементів дистанційного навчання у вищому навчальному закладі: погляди психолога / Т. Б. Тарасова // Фізико-математична освіта. - 2018. - Вип. 1. - С. 316-321.

23. Трегубова Е. С. Самостоятельная работа в высшей медицинской школе и ее роль в формировании личности будущего специалиста : материалы Всероссийской науч.-метод. конф. «Психолого-педагогические аспекты совершенствования качества медицинского и фармацевтического образования» посвященной 90-летию САМГМУ / Е. С. Трегубова, Е. С. Петрова, О. Б. Даутова. - 2009. - С. 160-161.

24. Фадеев Г. Н. Интегративно-аксиологический подход к созданию систем дистанционного образования / Г. Н. Фадеев // Дистанционное и виртуальное обучение. - 2013. - № 3. - С. 31-39. 


\section{REFERENCES}

1. Pro zatverdzhennia Polozhennia pro systemu bezperervnoho profesiinoho rozvytku fakhivtsiv u sferi okhorony zdorovia [On approval of the Regulations on the system of continuous professional development of specialists in the field of health care]. Postanova Kabinetu Ministriv Ukrainy vid 28 bereznia 2018 r. № 302 - Resolution of the Cabinet of Ministers of Ukraine of March 28, 2018 No 302 [in Ukrainian].

2. Andreyev, A. A., \& Soldatkin, V. I. (1999). Distantsionnoye obucheniye: sushchnost, tekhnologiya, organizatsiya [Distance learning: essence, technology, organization]. Moscow: Izd-vo MESI [in Russian].

3. Afanasyeva, A. A., \& Afanasyev, A. S. (2008). Ekspertnyye metody prinyatiya resheniy 0 vybore sistemy distantsionnogo obucheniya dlya poslediplomnogo meditsinskogo obrazovaniya [Expert methods of making decisions on the choice of a distance learning system for postgraduate medical education]. Proceedings of the $X V$ Vserossiyskoy nauchnometodicheskoy konferentsii «Telematika 2008» - XV All-Russian Scientific and Methodological Conference "Telematics 2008". Saint-Petersburg [in Russian].

4. Bezprozvanna, V. M., \& Parashchych I. M. (2008). Osoblyvosti pravovoho rehuliuvannia nadannia stomatolohichnykh posluh [Features of legal regulation of dental services]. Proceedings from: II Vseukrainska naukovo-praktychna konferentsiia "Medychne pravo Ukrainy: pravovyi status patsiientiv $v$ Ukraini ta yoho zakonodavche zabezpechennia (henezys, rozvytok, problemy $i$ perspektyvy vdoskonalennia)» - The II All-Ukrainian Scientific and Practical Conference "Medical law of Ukraine: the legal status of patients in Ukraine and its legislation (genesis, development, problems and prospects for improvement)" (pp. 30-33). Lviv: Vyd-vo LOBF "Medytsyna i pravo" [in Ukrainian].

5. Voronenko, Yu. V., \& Mintser, O. P. (2011). Bezperervnyi profesiinyi rozvytok likariv i provizoriv - novi pryntsypy pobudovy systemy [New principles of construction of continuousprofessional development system of doctors andpharmaceutists]. Medychna osvita - Medical Education, 2, 41-44 DOI: https://doi. org/10.11603/me.v0i2.862 [in Ukrainian].

6. Vyshnivskyi, V. V., Hnidenko, M. R., Haydur, H. I., \& Ilin, O. O. (2014). Orhanizatsiia dystantsiinoho navchannia. Stvorennia elektronnykh navchalnykh kursiv ta elektronnykh testiv: navch. posib. [Organization of distance learning. Creation of electronic training courses and electronic tests: textbook]. Kyiv: DUT [in Ukrainian].

7. Galiy, L. V., Shulga, L. I., Yakushchenko, V. A., Nartov, P. V., Burian, K. O., \& Bagan, S. O. (2019). Vprovadzhennia dystantsiinoi formy navchannia $\mathrm{V}$ systemu pisliadyplomnoi osvity: problemni pytannia sohodennia [Implementing the distance learning in the system of postgraduate education: problem issues of modernity]. Problemy bezperervnoi medychnoi osvity i nauky - Problems of Uninterrupted Medical Trainiang and Science, 3, 14-20 [in Ukrainian].

8. Hurevych, R.S., \& Kademiya, R.S. (2007). Informatsiinokomunikatsiini tekhnolohii $v$ navchalnomu protsesi $i$ naukovykh doslidzhenniakh [Information and communication technologies in the educational process and scientific research]. Kyiv: Osvita Ukrainy [in Ukrainian].

9. Grigoriev, N. N., Bobrovskaya, E. A., \& Grigoriev, S. N (2016). Aktualnyye voprosy obucheniya khirurgii [Actual questions in technologies of teaching surgery]. Sovremennyye problemy nauki i obrazovaniya - Modern Problems of Science and Education. Surgery, 4. Retrieved from: http://www.science-education.ru/ru/ article/view?id=24912 [in Russian].

10. Lebedeva, M. B., Agaponov, S. V., Goryunova, M. A., Kostikov, A. N., Kostikova, N. A., Nikitina, L. N., \& Shilova, O.N. (2010). Distantsionnyye obrazovatelnyye tekhnologii: proyektirovaniye i realizatsiya uchebnykh kursov [Distance educational technologies: design and implementation of training courses]. Lebedeva, M.B. (Ed.). 336 p. Saint-Petersburg: BKHV-Peterburg [in Russian].

11. Dudina, M.N. (2010). Novaya obrazovatelnaya paradigma: problemy soderzhaniya obrazovaniya [New educational paradigm: problems of the content of education]. Obrazovaniye i nauka - Education and Science, 2, 3-16 [in Russian].

12. Yeshchenko, A. V. (2013). Vykorystannia dystantsiinoho navchannia $\mathrm{v}$ systemi pisliadyplomnoi osvity: suchasne i maibutnie [The use of distance learning in the system of postgraduate education: present and future]. Problemy bezperervnoi medychnoi osvity $i$ nauky - Problems of Uninterrupted Medical Trainiang and Science, 2 (10), 5-0 [in Ukrainian].

13. Karkavina, D. Yu. (2007). Nastolnaya kniga patsiyenta, ili kak zashchitit svoi prava pri obrashchenii za meditsinskoy pomoshchyu [Patients handbook, or how to protect your rights when seeking medical help]. Rostov-na-Donu: Feniks [in Russian].

14. Kovalchuk, L. Ya. (2000). Osnovni tendentsii rozvytku svitovoi vyshchoi shkoly. Vprovadzhennia suchasnykh tekhnolohii v navchalnyi protses Ternopilskoi derzhavnoi medychnoi akademii im. I. Ya. Horbachevskoho: dosiahnennia i perspektyvy [The main trends in the development of world higher education. Introduction of modern technologies in the educational process of Ternopil State Medical Academy named after I. Horbachevsky: achievements and prospects]. Medychna osvita - Medical Education, 2, 5-11 [in Ukrainian].

15. Kukharenko, V. M., Rybalko, O. V., \& Syrotynko, N. H. (2002). Dystantsiine navchannia: umovy zastosuvannia: navch. posib. [Distance learning: conditions of application: textbook]. 3-e vyd. Kharkiv: NTU «KHPI», Torsinh [in Ukrainian].

16. Bolotina, N. B. (Eds.). (2001). Medychne pravo Ukrainy: Zbirnyk normatyvno-pravovykh aktiv [Medical law of Ukraine: collection of normative-legal acts]. Vydavnychyi Dim: «In Yure» [in Ukrainian].

17. Merkulova, O. G. (2012). Sovremennyy etap razvitiya obshchestva: problema terminologii [The modern stage of development of society: the problem of terminology]. Mezhdistsiplinarnyye issledovaniya $v$ nauke i obrazovanii - Interdisciplinary Research in Science and Education, 1, 26-30 [in Russian].

18. (2012). Natsionalna stratehiia rozvytku osvity $\mathrm{v}$ Ukraini na 2012-2021 roky [National strategy for the 
development of education in Ukraine for 2012-2021]. Retrieved from: http://www.nmu.edu.ua/legis2.php [in Ukrainian].

19. Olnev, A.S. (2015). Ispolzovaniye novykh tekhnologiy $\mathrm{v}$ distantsionnom obuchenii [The use of new technologies in distance learning]. Aktualnyye problemy sovremennoy nauki-Actual Problems of Modern Science, 1, 96 [in Russian].

20. Sokolova, I.I., Stoyan, O.Yu., \& Denysova, O.H. (2017). Pytannia formuvannia profesiinoi kompetentnosti likaria-stomatoloha $\mathrm{V}$ internaturi [Questions of formation of professional competence of a dentist in an internship]. Proceedings from 43 naukovo-metodychna konferentsiia, prysviachena 50-richchiu zapochatkuvannia internatury $v$ Kharkivskomu natsionalnomu medychnomu universyteti: "Suchasnyi stan ta perspektyvy pidhotovky likarivinterniv u Kharkivskomu natsionalnomu medychnomu universyteti» - 43-th Scientific Methodical Conference dedicated to the 50th anniversary of the internship at Kharkiv National Medical University: "Current state and prospects of training of interns at the Kharkiv National Medical University». Kharkiv: KHNMU [in Ukrainian]. 21. Symchuk, Kh.S. (2016). Perspektyvy ta problemy bezperervnoi osvity $\mathrm{v}$ simeinii medytsyni [Perspectives and problems of continuous education in family medicine]. Bukovynskyi medychnyi visnyk - Bukovynian Medical Herald, 4 (80), 246-249 [in Ukrainian].
22. Tarasova, T.B. (2018). Vykorystannia elementiv dystantsiinoho navchannia u vyshchomu navchalnomu zakladi: pohliady psykholoha [The use of elements of distance learning in higher education: the views of a psychologist]. Fizyko-matematychna osvita - Physical and Mathematical Education, 1, 316-321 [in Ukrainian]. 23. Tregubova, Ye.S., Petrova, Ye.S., \& Dautova, O.B. (2009). Samostoyatelnaya rabota v vysshey meditsinskoy shkole i yeye rol $\mathrm{v}$ formirovanii lichnosti budushchego spetsialista [Independent work in higher medical school and its role in shaping the personality of a future specialist]. Proceedings from Vserossiyskoy nauch.-metod. konf. "Psikhologo-pedagogicheskiye aspekty sovershenstvovaniya kachestva meditsinskogo i farmatsevticheskogo obrazovaniya" posvyashchennoy 90-letiyu SAMGMU - All-Russian Scientific Methodical Conference "Psychological and pedagogical aspects of improving the quality of medical and pharmaceutical education" dedicated to the 90th anniversary of SAMGMU (pp. 160-161) [in Russian].

24. Fadeyev, G.N. (2013). Integrativno-aksiologicheskiy podkhod $\mathrm{k}$ sozdaniyu sistem distantsionnogo obrazovaniya [Integrative-axiological approach to the creation of distance education systems]. Distantsionnoye $i$ virtualnoye obucheniye - Distance and virtual training, 3, 31-39 [in Russian]. 